\title{
Christelle Jullien. $\mathrm{VI}^{\mathrm{e}}$ siècle, un temps de réformes en Iran. Échos dans l'Église syro-orientale?
}

\section{Rédaction}

\section{Q OpenEdition}

1 Journals

\section{Édition électronique}

URL : http://journals.openedition.org/abstractairanica/40844

DOI : 10.4000/abstractairanica.40844

ISSN : 1961-960X

Éditeur:

CNRS (UMR 7528 Mondes iraniens et indiens), Éditions de l'IFRI

\section{Édition imprimée}

Date de publication : 1 décembre 2013

ISSN : 0240-8910

Référence électronique

Rédaction, «Christelle Jullien. Vle siècle, un temps de réformes en Iran. Échos dans l'Église syroorientale? », Abstracta Iranica [En ligne], Volume 32-33 | 2013, document 329, mis en ligne le 01 juillet 2016, consulté le 26 septembre 2020. URL : http://journals.openedition.org/abstractairanica/40844 DOI : https://doi.org/10.4000/abstractairanica.40844

Ce document a été généré automatiquement le 26 septembre 2020.

Tous droits réservés 


\section{Christelle Jullien. $\mathrm{VI}^{\mathrm{e}}$ siècle, un temps de réformes en Iran. Échos dans l'Église syro-orientale?}

\section{Rédaction}

\section{RÉFÉRENCE}

Christelle Jullien. « VI siècle, un temps de réformes en Iran. Échos dans l'Église syroorientale? ». Parole de l'Orient 33, 2008, p. 1-14.

1 Pour l'époque sassanide, dans la communauté syro-orientale de l'empire iranien, se met en place tout un processus d'élaborations hagiographiques des souverains en rois éclairés et ouverts, voire même chrétiens. Cette mise en contexte historique permet d'expliciter les intentions de ces pratiques d'écriture et les volontés politiques des autorités chrétiennes.

\section{AUTEURS}

\section{RÉDACTION}

Directeur de la revue et secrétariat (Paris) 